\title{
PENGEMBANGAN SISTEM INFORMASI MAHASISWA BERBASIS MOBILE ANDROID HYBRID MENGGUNAKAN WEBSERVICE STUDI KASUS: POLITEKNIK PGRI BANTEN, CILEGON
}

\author{
Khasan Asrori $^{1}$, Ely Nuryani ${ }^{2}$, Waliadi Gunawan ${ }^{3}$ \\ Dosen Fakultas Ilmu Komputer Universitas Banten Jaya \\ Jl. Syeh Nawawi Al Bantani, Curug, Kota Serang Banten \\ E-mail: khasanasrori@gmail.com¹, elynuryani@unbaja.ac.id² \\ waliadigunawan@unbaja.ac.id ${ }^{3}$
}

\begin{abstract}
The development of mobile technology is currently widely used by android smartphone, especially the most widely used. The need to use this technology is very much needed as a mobile-based information service media. The information service system for students at Politeknik PGRI Banten is currently computerized by utilizing web-base technology not yet following the development of mobile technology. Therefore, the development of a hybrid android based mobile information system service was carried out with the aim of developing an existing service system into mobile smartphone-based system service. From the results of the study, the utilization of student information system techonlogy services based on hybrid android mobile and supported by pus notification in real time can help financial and academic departements in providing information related to lecture payments and information related to lecture schedules.
\end{abstract}

Keywords : android, hybrid, information system, Notification, Real Time

\section{PENDAHULUAN}

Seiring dengan perkembangan teknologi yang semakin pesat serta pengguna smart phone yang begitu banyak, maka suatu instansi maupun perusahaan sangat membutuhkan suatu sistem informasi yang terkomputerisasi dalam pengolahan data setiap kegiatannya. Informasi sudah semakin mudah diakses dan berbagai macam bentuk yang ada didalam informasi terutama informasi akademik yang dewasa ini sangatlah penting bagi kalangan mahasiswa maupun civitas akademik terutama pada pengolahan data-data. Penggunaan teknologi informasi pada bidang pendidikan memiliki potensi besar untuk menciptakan tujuan-tujuan pembelajaran dan menciptakan sistem informasi yang sangat berguna bagi sebuah kebutuhan perguruan tinggi. 
Politeknik PGRI Banten sebagai lembaga pendidikan yang terletak di tengah kota Serang dan Cilegon di Banten telah memiliki sistem informasi akademik yang terintegrasi yang dikembangkan oleh penulis sebelumnya, sistem informasi tersebut dinamakan sebagai smart campus yang bertujuan untuk mampu menangani segala permasalahan pada disetiap civitas akademik seperti pada bagian marketing untuk mengola calon mahasiswa, bagian keuangan untuk mengolah data-data administrasi, bagian akademik untuk mengolah serta memantau perkembangan mahasiswa, bagian mahasiswa untuk memonitoring hasil dari perkuliahan serta dosen untuk memantau perkembangan mahasiswa. Sistem informasi ini dapat diakses secara online di komputer maupun di smart phone yang sifatnya sudah responsive melalui browser.

Suatu yayasan lembaga pendidikan memerlukan pengolahan manajemen yang baik untuk melayani kebutuhan mahasiswa maupun dosen, untuk itu proses administrasi pembayaran dan pengolahan jadwal perkuliahan sangatlah berperan di lembaga pendidikan. Salah satu informasi yang sangat dibutuhkan oleh perguruan tinggi Politeknik PGRI Banten yaitu informasi mengenai pembayaran administrasi perkuliahan dan jadwal perkuliahan yang real time, informasi ini sangat berpengaruh demi kelancaran dan ketertiban mahasiswa terhadap tanggung jawab sebagai mahasiswa di Politeknik PGRI Banten.

Pada dasarnya pekerjaan pengolahan informasi akademik pada Politeknik PGRI Banten sudah menggunakan sistem yang terintegrasi dengan memanfaatkan teknologi berbasis aplikasi web, akan tetapi mengingat permasalahan yang perlu segera diatasi terkait dengan pengembangan aplikasi sistem di Politeknik PGRI Banten adalah bagaimana memberikan informasi terkait pembayaran administrasi perkuliahan dan jadwal perkuliahan di saat Kegiatan Belajar-Mengajar (KBM) secara real time.

Maka untuk mempermudah hal di atas, perlu dilakukan penelitian untuk memanfaatkan teknologi internet dan komputer untuk kelancaran proses distribusi informasi akademik dalam bentuk sebuah alat bantu dengan memanfaatkan Web Service yang berjalan pada platform Android. Oleh karena itu penulis tertarik untuk mengembangakan sebuah aplikasi berbasis sistem platform android yang dapat mengatasi permasalahan di atas. 
Hasil yang diharapkan dari penelitian ini adalah segala permasalahan yang ada dapat diselesaikan sehingga mahasiswa mendapatkan informasi pembayaran administrasi perkuliahan dan jadwal perkuliahan secara real time.

\section{METODE PENELITIAN}

Penelitian ini dilakukan pada Perguruan Tinggi Politeknik PGRI Banten dan metode digunakan dalam penelitian ini adalah sebagai berikut :

a. Observase : pengumpulan data yang tidak hanya mengukur sikap dari responden namun juga dapat digunakan untuk merekam berbagai fenomena yang terjadi.

b. Interview : pengumpulan data yang dilakukan melalui tahap muka dan tanya jawab langsung antara pengumpulan data maupun peneliti terhadap nara sumber atau sumber data.

c. Research : pengumpulan data dengan mengambil data dari berbagai sumber seperti buku, majalah dan hasil penelitian orang lain yang berkaitan dengan pembahasan penelitian.

\section{HASIL DAN PEMBAHASAN}

Mengenai hasil dari penelitian yang diambil berdasarkan data yang telah terkumpul dengan menggunakan metode observasi, wawancara dan studi dokumentasi, hasil yang diperoleh sebagai berikut :

\section{Hasil Observasi}

Hasil pengamatan yang telah dilakukan peneliti terhadap sistem yang telah berjalan selama penelitian di Politeknik PGRI Banten yaitu :

1. Belum adanya metode pembayaran yang secara real time disaat waktu yang telah ditentukan untuk melakukan pembayaran.

2. Belum adanya sistem yang user friendly sehingga mahasiswa tidak lagi kesulitan mencari informasi.

3. Belum adanya aplikasi berbasis smartphone yang diterapkan untuk mengetahui informasi akademik yang sedang berlangsung. 
4. Belum adanya metode penjadwalan perkuliahan secara real time disaat waktu kegiatan belajar mahasiswa.

\section{Hasil Wawancara}

Hasil wawancara yang dilakukan peniliti terhadap Politeknik PGRI Banten kepada beberapa bagian civitas yang terkait, antara lain :

1. Responden : Ketua Yayasan Perguruan Tinggi

Tujuan : Mengetahui tingkat kebutuhan sistem yang ada pada Politeknik PGRI Banten

2. Responden : Bagian Keuangan

Tujuan : Mengetahui prosedur pembayaran administrasi perkuliahan serta berapa jumlahnya tiap angkatan / semester.

3. Responden : Bagian Akademik

Tujuan : Mengetahui prosedur kegiatan akademik dan jadwal perkuliahan secara berkala dan mengetahui dosen yang tersedia maupun ruangan yang ada.

4. Responden : Mahasiswa

Tujuan : Mengetahui tentang sejauh mana manfaat sistem informasi mahasiswa berbasis smartphone.

\section{Hasil Studi Dokumentasi}

Hasil studi dokumentasi peneliti terhadap Politeknik PGRI Banten adalah sebagai berikut :

1. Peneliti mengambil data mengenai profile Politeknik PGRI Banten dari buku pedoman akademik, website dengan situs www.politeknikpgribanten.ac.id, media cetak, serta media elektronik.

2. Peneliti mengambil data pembayaran administrasi dari bagian keuangan.

3. Peneliti mengambil data jadwal matakuliah dari bagian akademik. 


\section{HASIL IMPLEMENTASI}

Tahapan ini adalah merupakan bagian dari penerapan perancangan sistem kedalam kondisi yang seberannya, bertujuan agar diketahui bahwa sistem tersebut dapat dijalankan sesuai yang diharapkan atau tidak diharapkan serta dapat menghasilkan output yang sesuai. Sistem informasi mahasiswa berbasis android hybrid ini telah ada didalam penyimpanan layanan konten digital yang dimiliki oleh google yakni Playstore.

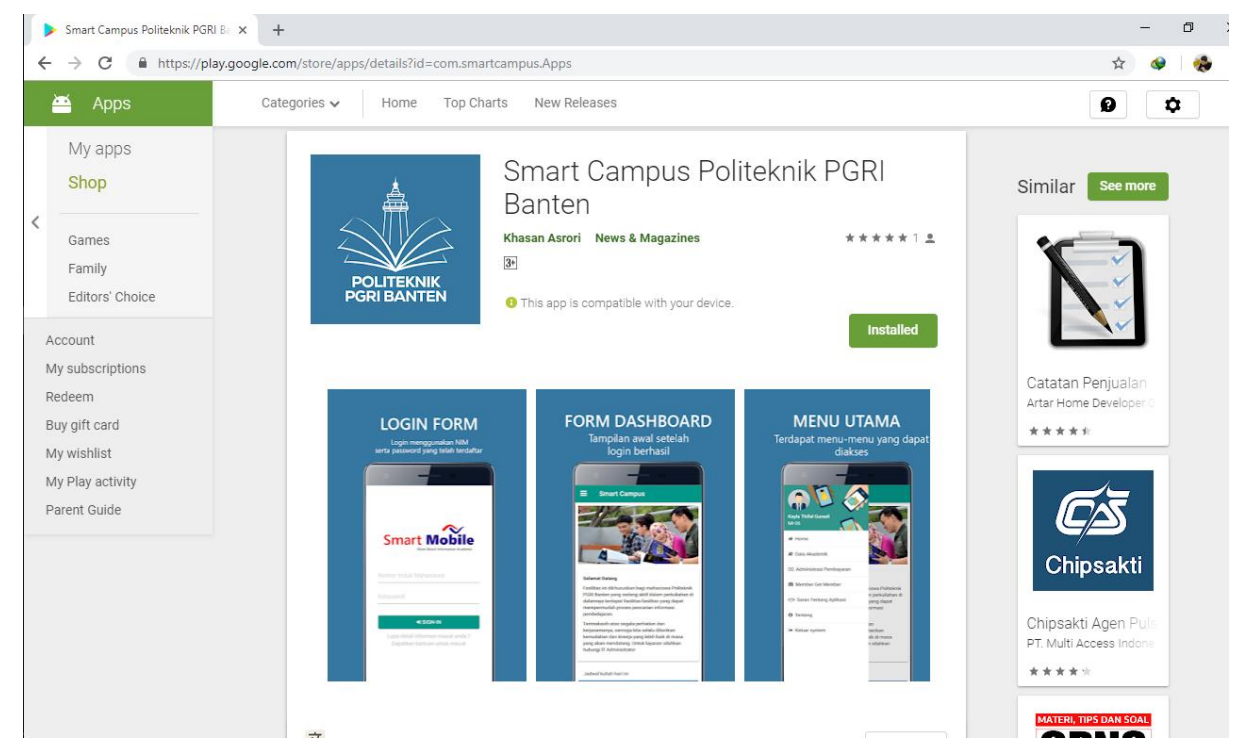

Gambar 1. Penyimpanan layanan konten digital

Dalam menjalankan sistem ini mahasiswa hanya membutuhkan perangkat smart phone yang berbasis android serta memiliki sistem operasi android 5.0 (kitkat). 


\section{HASIL IMPLEMENTASI SISTEM}

\section{A. Halaman Login}

Menampilkan halaman login dimana mahasiswa wajib mengisi nomor induk mahasiswa dan password untuk mengakses aplikasi. Nomor induk mahasiswa didapatkan setelah mahasiswa terdaftar di kampus Politeknik PGRI Banten, serta password diberikan secara default dan diharapkan untuk mengganti password.

\section{Smart Mobile}

Nomor Induk Mahasiswa

Katasandi

$\rightarrow$ SIGN-IN

Lupa detail informasi masuk anda ? Dapatkan

bantuan untuk masuk

Gambar 2. Halaman Login 


\section{B. Halaman Utama}

Menampilkan rancangan halaman utama dari aplikasi setelah mahasiswa dinyatakan benar oleh sistem setelah melewati tahap login. Dari halaman ini mahasiswa disambut dengan kata-kata pembukaan dari aplikasi serta dapat melihat langsung jadwal perkuliahan secara on time.

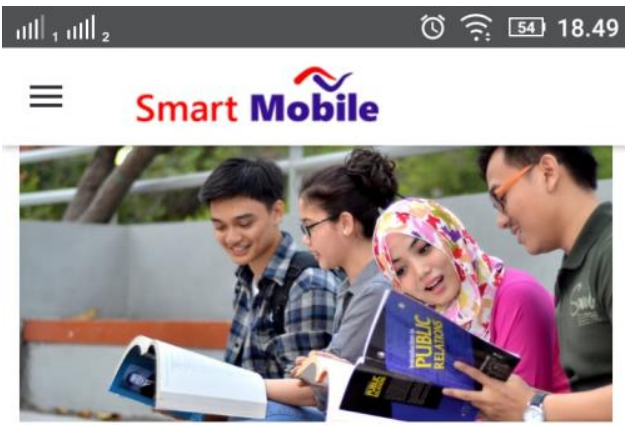

Selamat Datang Kayla Thifal Gunadi

Fasilitas ini dikhususkan bagi mahasiswa

Politeknik PGRI Banten yang sedang aktif dalam perkuliahan di dalamnya terdapat fasilitasfasilitas yang dapat mempermudah proses pencarian informasi pembelajaran.

Terimakasih atas segala perhatian dan kerjasamanya, semoga kita selalu diberikan kemudahan dan kinerja yang lebih baik di masa yang akan mendatang. Untuk layanan silahkan hubungi IT Administrator

Kabar Poltek

4 Rahasia Cerdas Untuk Meningkatkan .....

Gambar 3. Halaman Menu Utama 


\section{Notifikasi Pembayaran}

Menampilkan notifikasi tentang pembayaran perkuliahan, notifikasi ini akan muncul pada semua smart phone android yang terinstal aplikasi smart campus pada akhir bulan di setiap tanggal 26 jam 18.00 .

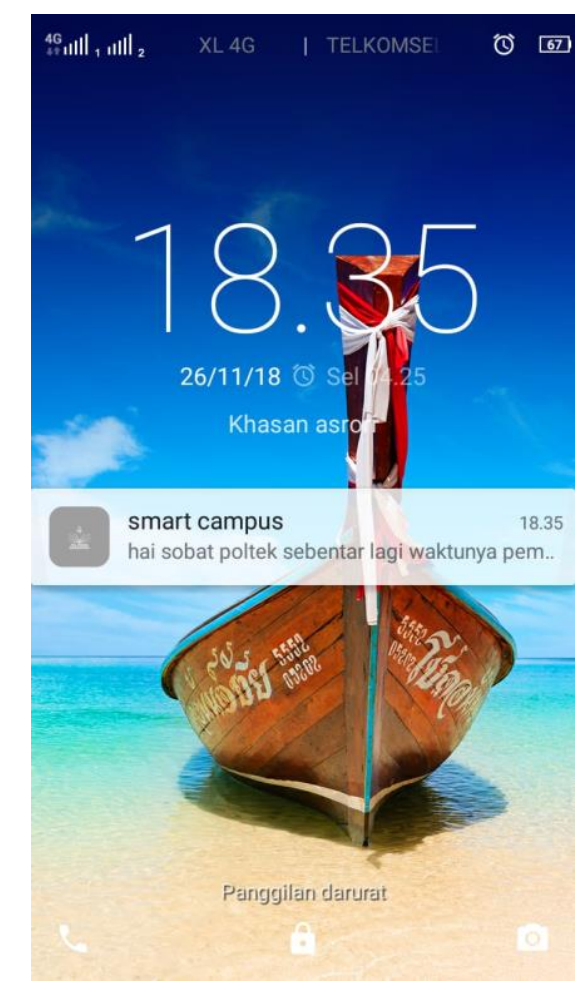

Gambar 4. Notifikasi pembayaran 


\section{Notifikasi Jadwal Perkuliahan}

Menampilkan notifikasi jadwal perkuliahan selama perkuliahan sedang perlangsung. Pada kasus ini terdapat kelas Managemen Informatika (MI) sedang terdapat jadwal perkuliahan pada jam 19.00 dengan matakuliah pemrograman (VB.NET).

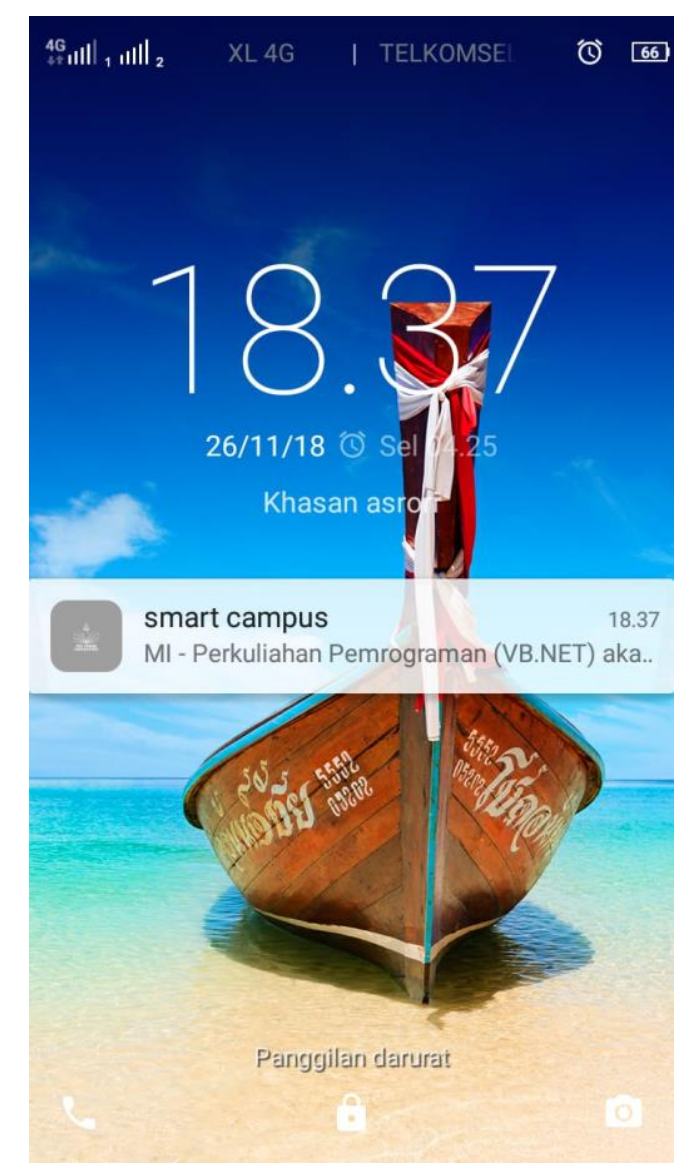

Gambar 5. Notifikasi jadwal perkuliahan 


\section{KESIMPULAN}

Dari serangkaian penelitian yang telah dilakukan dengan berbagai macam cara yaitu pengujian dan percobaan, bahwa dapat ditarik kesimpulan antara lain :

a. Informasi pembayaran administrasi perkuliahan pada perguruan tinggi Politeknik PGRI Banten dapat dengan mudah diketahui oleh mahasiswa dari aplikasi yang terinstal di smartphone melalu notification di setipa akhir bulan.

b. Penggunaan aplikasi sistem informasi mahasiswa berbasis android hybrid mahasiswa akan selalu diingatkan setiap jadwal perkuliaahan berjalan melalui notification.

c. Hasil evaluasi sistem terhadap aplikasi ini diambil menggunakan secara menyebarkan angket atau kuesioner dari 50 responden menyatakan bahwa sistem ini telah layak digunakan dengan ketentuan 51\% setuju untuk kategori kecepatan akses aplikasi, $57 \%$ setuju untuk kategori kepuasan pengguna dan $47 \%$ sangat setuju untuk kategori keamanan data.

\section{SARAN}

Dari kesimpulan di atas yang dapat penulis berikan saran yang ditujukan kepada pihak yayasan, sebagai bahan pertimbangan adalah :

a. Menyediakan ruang atau hosting yang lebih luas dikarenakan penampungan data akan setiap hari terupdate atau tersimpan.

b. Menambahkan fitur portal berita tentang kampus sehingga mahasiswa dapat lebih mengetahui segala informasi.

c. Menambahkan fitur ebook pada aplikasi sistem informasi mahasiswa berbasis android sehingga mahasiswa tidak perlu lagi membawa buku.

d. Pada perguruan tinggi Politeknik PGRI Banten perlu adanya peningkatan sumber daya manusia yang terkaitan dengan dunia informasi dan teknologi supaya proses pengembangan dunia IT dapat berjalan dengan baik. 


\section{REFRENSI}

Andhika Maheva Wicaksono., Teguh Sutanto., Julianto Lemantara. (2017). Rancang Bangun Sistem Informasi Cyber Campus (SICyCa) Berbasis Mobile Android Pada Institut Bisnis dan Informatika STIKOM Surabaya. JSIKA Volume 06 No 08 Tahun 2017. ISSN : 2338-137X.

Andre. (2014). Pengertian dan Fungsi Javascript dalam Pemrograman Web. Diambil Dari Sumber https://www.duniailkom.com/tutorial-belajar-javascript-pengertiandan-fungsi-javascript-dalam-pemograman-web/.

Andy Prasetyo Utomo. (2014). Pemodelan Arsitektur Enterprise Sistem Informasi Akademik Pada Perguruan Tinggi Menggunakan Enterprise Architecture Planning. Jurnal SIMETRIS, Volume 5 No 1 April 2014. ISSN : 2252-4983.

Dani Wijaya Sitorus., Edhy Sutanta., Suraya. (2016). Sistem Administrasi Akademik Berbasis Mobile Menggunakan Android Studi Kasus IST AKPRIND Yogyakarta. Jurnal SCRIPT Volume 3 No 2 Juni 2016.

Edhy Sutanta., Khabib Mustofa. (2012). Kebutuhan Web Service Untuk Sinkronasi Data Antar Sistem Informasi Dalam e-Gov Di Pemkab Bantul Yogyakarta. Jurtik - STMIK Bandung Edisi Mei 2012.

Eifel Rio Choiri., Beny., Agus Nugroho. (2015). Perancangan Aplikasi Informasi Tempat Pembuangan Sampah Terdekat Di Kota Jambi Berbasis Android Studi Kasus Dinas Kebersihan Kota Jambi. Jurnal Ilmiah Media Processor Volume 10 No 2 Oktober 2015. ISSN : 1907-6738.

Hanif Al Fata., Robert Marco. (2015). Analisis Pengembangan Dan Perancangan Sistem Informasi Akademik Smart Berbasis Cloud Computing Pada Sekolah Menengah Umum Negeri (SMUN) Di Daerah Istimewa Yogyakarta. Jurnal Telematika. Volume 8 No 2 Agustus 2015. ISSN : 1979-925X e-ISSN : 24424528.

I Wayan Gede Suma Wijaya. (2014). Penerapan Web Service Pada Aplikasi Sistem Akademik Pada Platform Sistem Operasi Mobile Android. Teknik Informatika, STIKOM PGRI Banyuwangi.

John M. Wargo. (2013). Apache Cordova 3 Programming. Addison Wesley. ISBN13: 978-0-321-95736-8. ISBN-10: 0-321-95736-9.

M. Ansyar Bora, Zeri Yusdinata. (2017). Evaluasi Penggunaan Sistem Informasi Administrasi Akademik (SIAKAD) STT Ibnu Sina Batam. Jurnal Responsive Volume 1 No.1 Desember 2017. ISSN : 2614-7602.

Mita Septiana Chumairoh., Budiman., Diema Hernyka Satyareni. (2014). Perancangan Bangun Aplikasi Mobile Pada Platform Android Berbasis HTML5 Studi Kasus Layanan Informasi Website UNIPDU Jombang. Jurnal Ilmiah Edutic Volume 1 no 1 November 2014. ISSN : 2407-4489. 
Naim. (2017). Pengertian, Fungsi, Tujuan dan Sejarah CSS. Diperoleh dari sumber https://naimlogdasar.blogspot.com/2017/05/pengertian-fungsi-tujuan-dansejarah-css.html.

Nicky Rolly., Nashrul Hakiem. (2015). Pengembangan Aplikasi Mobile Academic Information System (AIS) Berbasis Android Untuk Pengguna Dosen Dan Mahasiswa Studi Kasus Pusat Teknologi Informasi Dan Pangkalan Data UIN Syarif Hidayatullah Jakarta. Jurnal Teknik Informatika Volume 8 No 1 April 2015.

Novi Nuari. (2014). Perancangan Aplikasi Layanan Mobile Informasi Administrasi Akademik Berbasis Android Menggunakan Webservice Studi Kasus REG B Universitas Tanjungpura. Program Studi Teknik Informatika Jurusan Teknik Elektro. Fakultas Teknik Universitas Tanjungpura.

Otto Fajarianto. (2016). Prototype Pelayanan Akademik Terhadap Komplain Mahasiswa Berbasis Mobile. Jurnal Lentera ICT. Volume 3 No 1 Mei 2016. ISSN : 2338-3143.

Rafii Rizqullah. (2018). Onsen UI, Rekomendasi UI Framework Untuk Para Developer Phonegap. Diambil Dari Sumber https://www.codepolitan.com/onsen-ui-rekomendasi-ui-framework-untuk-paradeveloper-phonegap-5ae092534b2e5.

Raymond K. Camden. (2016). Apache Cordova In Action. Manning Publications CO. 20 Baldwin Road. Shelter Island, NY 11964.

Reni Haerani., Moedjiono. (2015). Prototipe Sistem Informasi Akademik Perguruan Tinggi Berbasis Web Studi Kasus STIE Al-Khairiyah Cilegon. Program Studi Magister Ilmu Komputer. Universitas Budi Luhur.

Rosa A.S., M. Shalahuddin. (2014). Rekayasa Perangkat Lunak Terstruktur dan Berorientasi Objek. Informatika Bandung. ISBN : 978-602-1514-05-4.

Syarif Mujab., Kodrat Imam Satoto., Kurniawan Teguh Martono. (2014). Perancangan Sistem Informasi Akademik Berbasis Mobile Web Studi Kasus di Program Studi Sistem Komputer Universitas Diponegoro. Makalah Seminar Tugas Akhir.

Yana Permana. (2016). Ini Dia Perbedaan Aplikasi Native, Hybrid atau Web. Diambil Dari Sumber https://www.codepolitan.com/apa-bedanya-aplikasi-nativehybrid-dan-web. 